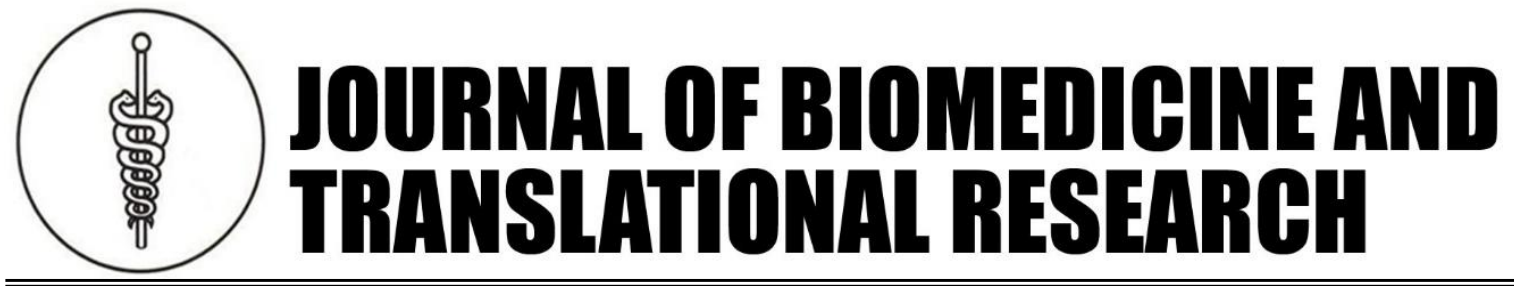

Copyright $@ 2018$ by Faculty of Medicine Diponegoro University and Indonesian Medical Association, Central Java Region

\title{
The Effects of Zinc Supplementation on Immune Response of Obese Children With Family History of Atopy
}

\author{
Dewi Ratih$^{1}$, Mulyonoํㅜ, Saekhol Bakri², Wistiani*1 \\ ${ }^{1}$ Department of Pediatric Health, Faculty of Medicine, Diponegoro University, Semarang, Indonesia \\ ${ }^{2}$ Department of Community Health, Faculty of Medicine, Diponegoro University, Semarang, Indonesia
}

\section{Article Info}

History:

Received: 02 Nov 2018

Accepted: 09 Nov 2018

Available: 31 Dec 2018

\begin{abstract}
Background: Obesity is associated with low-grade chronic inflammation and imbalance of T helper 1 and T helper 2 cells-cytokine production, also associated with risk of allergy. Zinc plays role in balancing immune response and have antiinflammatory effects; its deficiency is common in person with obesity. We investigate the role of zinc supplementation in obese children with hypozincaemia who has risk of allergy which identified as having positive family history of atopy. Materials and Method: We performed double blind randomized controlled trial to investigate the effect of once daily $15 \mathrm{mg}$ zinc supplementation for 6 weeks in children aged 11 to 14 years old with obese and hypozincaemia who has family history of atopy. Subjects were divided into group of zinc supplementation and placebo, recruited from junior high schools from Semarang municipality, performed during periods from January to December 2013. Serum zinc concentration, leptin, immunoglobulin-E (Ig-E), T helper1 cytokine interferon- $\gamma$ (IFN- $\gamma$ ), T helper2 cytokine interleukin-4 (IL-4) were measured, also body weight, height and ISAAC questionnaire to recruit subjects with family history of atopy.

Result: There were 36 subjects. The concentration of zinc serum, Ig-E, IFN- $\gamma$, and IL-4 of two groups before supplementation were not significantly different ( $p>0.05)$. Zinc supplementation increase the mean level of zinc concentration on treatment group compare to placebo group $(\mathrm{p}=0.000)$. The mean concentration serum were decreased at treatment group in level of Ig-E $(p=0.613)$, IFN- $\gamma(p=0.174)$ and IL-4 $(\mathrm{p}=0.085)$ but not statisticaly significant.

Conclusion: Zinc supplementation improves the hypozincaemia state in obese children with family history of atopy, and associated with possible decreased risk of allergy.
\end{abstract}

Keywords: obese children; atopy; zinc supplementation. Permalink/ DOI: https://doi.org/10.14710/jbtr.v4i2.3520

\section{INTRODUCTION}

Obesity in children has emerged as a serious clinical burden in health, posing them to have increase risk of cardiovascular, metabolic diseases ${ }^{1}$ and allergy. ${ }^{2}$ The correlation between obesity and atopy are still in debate; one study showed no association between obesity and atopy in schoolchildren ${ }^{3}$ meanwhile other showed there were correlation between obesity and the level of Ig-E concentration, atopy and food sensitization. ${ }^{4}$ World Health Organization defines obesity as abnormal or excessive fat accumulation which impair health. ${ }^{5}$ The excess of fat accumulation are associated with enlarge adipocytes which then recruits macrophages and promotes the condition of low-grade chronic inflammation due to dominant state of Th1-cytokines production IFN- $\gamma$ compare to Th2-cytokine profile production such as IL-4. ${ }^{6,7}$

\footnotetext{
* Corresponding author:

E-mail:wistiani@yahoo.com
} 
Leptin which is secreted by adipose tissue has known to play role in regulating immune function as a link between obesity and proinflammatory state ${ }^{8,9}$. Leptin resistance commonly found in obesity is correlated with defective receptor, receptor polymorphism, imbalance between circulating leptin and bound leptin. That condition suppress the cytokine production of Th1 cells towards the increase production of Th2-cytokines such as IL-4, IL-5 and IL-13. Interleukin-4 has role on the production of Ig-E which known as marker of allergy $^{10-13}$.

Zinc is an essential trace elements which also has anti-oxidant and anti-inflammation properties ${ }^{14}$, its concentration found low in obese individual ${ }^{15}$. Study showed that zinc deficiency make the Th1/Th2 balance disrupted, lead to decrease level of Th1-cytokine production but without any significance alternation on Th-2 cytokine production. This study aims to investigate the effects of zinc supplementation on obese children with hypozincaemia who has risk of allergy which identified as having family history of atopy.

\section{MATERIALS AND METHODS \\ Subjects and Controls}

The double blind randomized controlled trial was conducted among 40 obese children ages 11-14 years old, recruited from yunior high school students in Semarang municipality during period from January to December 2013. Participants were recruited from 1268 students, selected by inclusion criteria such as body mass index (BMI) equal to or higher than $25 \mathrm{~kg} / \mathrm{m}^{2}$ according to obese criteria by WHO standard for Asia Pacific children, positive family history of atopy justified according to The International Study of Asthma and Allergies in Childhood (ISAAC) questionaire, serum zinc level below normal concentration (hypozincaemia). Children with history of metabolic or chronic diseases, chronic gastrointestinal tract dysfunction or liver diseases and zinc treatment before recruitment, were excluded from the study.

The study was approved by the Ethics Committee of Faculty of Medicine Diponegoro University and Dr.
Kariadi Hospital number 320/EC/FK/RSDK/2013 and was conducted according to the Declaration of Helsinki. We provided detailed information on the study procedure to children and parents, followed by written informed consent from the parents and oral assent from the children.

\section{Physical Examination and Anthropometric Measurement}

At enrollment we performed physical examination consist of general condition, vital signs (blood pressure, pulse, respiration rate, temperature), measurement of body weight by electric scale SECA 878 with degree of measurement 100 gram, subjects wore light-weighted cloth. Standing height measurement performed on erect position, bare foot, measured by standardized stadiometer with 0.1 centimeter accuracy. The ISAAC questionaire was performed to identify the family history of atopy and history of allergy of the subjects.

\section{LABORATORY MEASUREMENTS}

Eight mililiters of blood were withdrawn from subjects after at least 12 hours fasting, examiner wore sterile polyethylene gloves, with non-coagulated vacutainer, free from trace element demineralized by $30 \%$ nitric acid one day before examination, flushed by demineralized aqua to avoid contamination of other minerals. Blood were withdrawn twice, first before zinc supplementation and the second at 6 weeks after supplementation.

Measurement of zinc serum were performed by Atomic Absorbtion Spectrophotometer (AAS) methods, leptin, Ig-E and cytokine concentration (IFN$\gamma$, IL-4) were measured by Elisa methods at acredited GAKY Laboratory Faculty of Medicine Diponegoro University.

\section{Intervention}

Treatment group were given once daily zinc sulphate syrup $15 \mathrm{mg}$ for 6 weeks. Placebo group were given syrup contain of nipagin, simplex syrup and carboxyl methyl cellulose according to manual procedure of Pharmacy Department of Faculty of

Table 1. Characteristics of subjects

\begin{tabular}{|c|c|c|c|}
\hline \multirow[b]{2}{*}{ Characteristic } & \multicolumn{2}{|c|}{ Groups } & \multirow[b]{2}{*}{$p$} \\
\hline & $\begin{array}{l}\text { Zinc supplementation } \\
\text { n }(\%)\end{array}$ & $\begin{array}{l}\text { Placebo } \\
\text { n }(\%)\end{array}$ & \\
\hline \multicolumn{4}{|l|}{ Sex } \\
\hline - Boys & $10(27.8)$ & $11(30.6)$ & $0.73 *$ \\
\hline - Girls & $8(22.2)$ & $7(19.4)$ & \\
\hline \multicolumn{4}{|l|}{ BMI } \\
\hline - obese & $12(33.3)$ & $11(30.6)$ & $0.72 *$ \\
\hline - $\quad$ superobese & $6(16.7)$ & $7(19.4)$ & \\
\hline \multicolumn{4}{|l|}{ Family history of atopy } \\
\hline - Atopic Dermatitis & $7(19.4)$ & $12(33.3)$ & $0.17 *$ \\
\hline - Rhinitis & $7(19.4)$ & $5(13.9)$ & \\
\hline - Asthma & $4(11.1)$ & $1(2.8)$ & \\
\hline
\end{tabular}

* Chi square test 


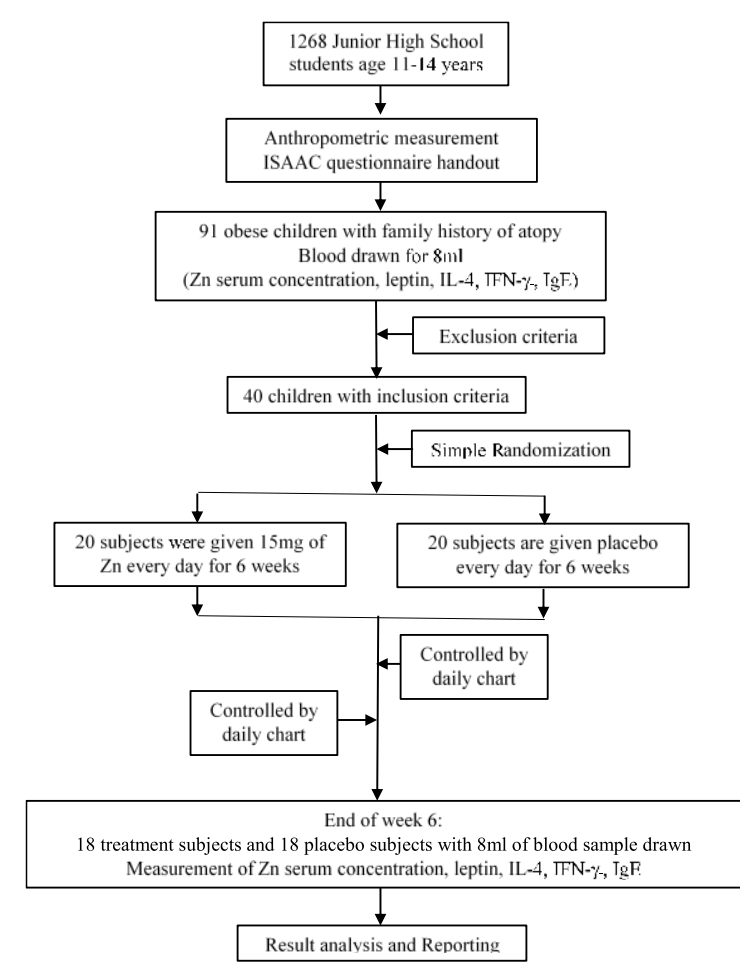

Figure 1. Consort Diagram

Medicine Diponegoro University. The parents were given daily chart consumption of diet, list of drugs consumed if any and check list to evaluate the adherence of zinc supplementation.

\section{Statistical Analyses}

The difference of zinc serum, leptin, Ig-E and cytokine concentration before and after supplementation were tested by paired t-test for normal distribution or Wilcoxon Signed Ranked Test if the distribution were not normal. The mean difference of zinc serum, leptin, Ig-E and cytokine concentration between group of supplementation and placebo were tested by non-paired t-test for normal datas distribution or Mann Whitney test for not normal datas distribution. Datas were analyzed by SPSS for windows version 15.0 (SPSS Inc, USA).

\section{RESULTS}

During period of study there were 91 obese children with family history of atopy; among them there were 41 subjects with hypozincaemia which then randomly asigned to 2 groups of treatment group of 20 subjects who received once daily $15 \mathrm{mg}$ of zinc sulphate syrup for 6 weeks and placebo group of 20 subjects. At the end of the study there were remaining 18 subjects of treatment group and 18 subjects of placebo group as shown in Consort Diagram of Figure 1. Four subjects resigned due to unexplained reason.

Table 1 showed characteristics of subjects; there were no significance difference of age, sex and degrees of obesity between treatment and placebo groups. The clinical manifestation of allergy consist of atopic dermatitis, allergic rhinitis and asthma.

Table 2 showed that mean concentration of zinc serum, leptin, Ig-E, IFN- $\gamma$ and IL-4 before supplementation on treatment group were lower compare to placebo group;

Table 2. Laboratory examination before and after supplementation

\begin{tabular}{|c|c|c|c|c|c|c|c|c|c|}
\hline & \multicolumn{3}{|c|}{ Pre intervention } & \multicolumn{3}{|c|}{ Post intervention } & \multirow[t]{2}{*}{$\mathrm{P}$} & \multirow[t]{2}{*}{$\Delta$ mean } & \multirow[t]{2}{*}{$\mathrm{P}$} \\
\hline & Mean & Min & Max & Mean & Min & Max & & & \\
\hline Leptin & & & & & & & $0.460^{\psi}$ & & \\
\hline $\begin{array}{l}\text { Treatment } \\
\text { control }\end{array}$ & $\begin{array}{l}8824.56 \\
9908.72\end{array}$ & $\begin{array}{l}2459.50 \\
1775.70\end{array}$ & $\begin{array}{l}17279.00 \\
15874.00\end{array}$ & & & & & & \\
\hline Zinc (ng/dl) & & & & & & & & & $0.000^{¥}$ \\
\hline Treatment & 69.57 & 62.75 & 78.11 & 94.31 & 78.21 & 120.53 & $0.000^{¥}$ & 24.74 & \\
\hline control & 71.97 & 64.40 & 79.00 & 75.44 & 67.17 & 81.50 & $0.000^{¥}$ & 3.47 & \\
\hline $\mathrm{Ig}-\mathrm{E}(\mathrm{IU} / \mathrm{ml})$ & & & & & & & & & $0.613^{\alpha}$ \\
\hline Treatment & 141.78 & 4.573 & 392.38 & 126.46 & 3.21 & 361.06 & $0.001^{¥}$ & -15.50 & \\
\hline Control & 120.98 & 10.59 & 282.41 & 100.96 & 5.51 & 264.60 & $0.018^{\S}$ & -20.02 & \\
\hline IFN- $\gamma(\mathrm{pg} / \mathrm{ml})$ & & & & & & & & & $0.174^{\alpha}$ \\
\hline Treatment & 4.44 & 0.25 & 13.34 & 2.61 & 0.08 & 10.94 & $0.035^{\S}$ & -1.82 & \\
\hline Control & 4.80 & 0.25 & 14.84 & 3.89 & 0.08 & 15.80 & $0.323^{¥}$ & -0.91 & \\
\hline IL-4 (pg/ml) & & & & & & & & & $0.085^{\alpha}$ \\
\hline Treatment & 5.82 & 0.25 & 23.18 & 1,060 & 0.12 & 2.52 & $0.000^{\S}$ & -4.76 & \\
\hline control & 3.92 & 0.25 & 14.55 & 1.47 & 0.12 & 4.72 & $0.157^{\S}$ & -2.44 & \\
\hline
\end{tabular}

$¥$ Paired t-test; $\S$ Wilcoxon signed rank test; $\psi$ independent t-test; $\alpha$ Mann-Whitney U test $\alpha$ Normal value : zinc (80-120 ng/dl); Ig-E (<100 IU/ml), IFN- $\gamma(15.6$ pg/ml), IL-4 (31,2 pg/ml) 
but there were no significantly difference between two groups. Result of our study showed mean value of IgE, IFN- $\gamma$ and IL-4 were in wide range distribution of cytokines value.

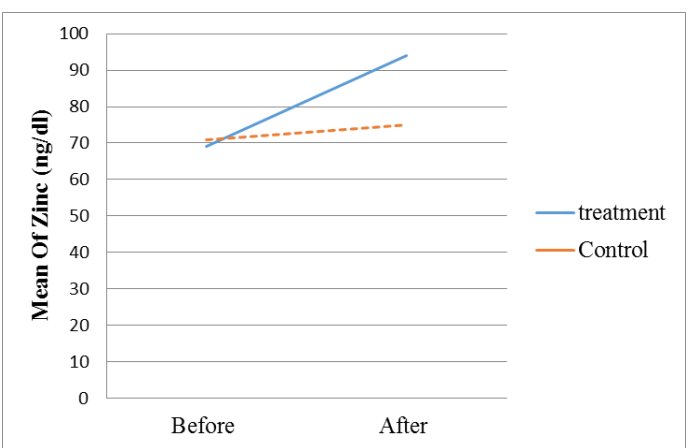

Figure 2. Mean of zinc serum between before and after intervention for 6 weeks

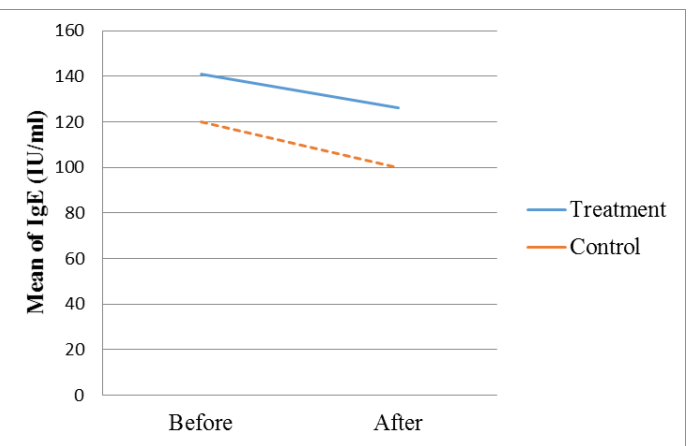

Figure 3. Mean of Ig-E serum between before and after intervention for 6 weeks

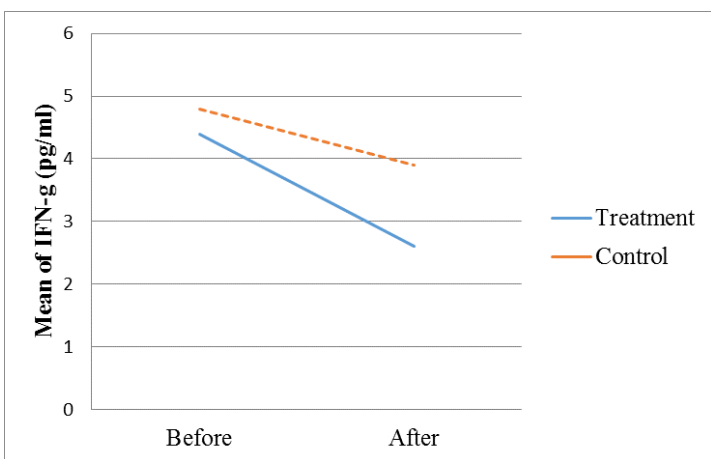

Figure 4. Mean of IFN- $\gamma$ serum between before and after intervention for 6 weeks

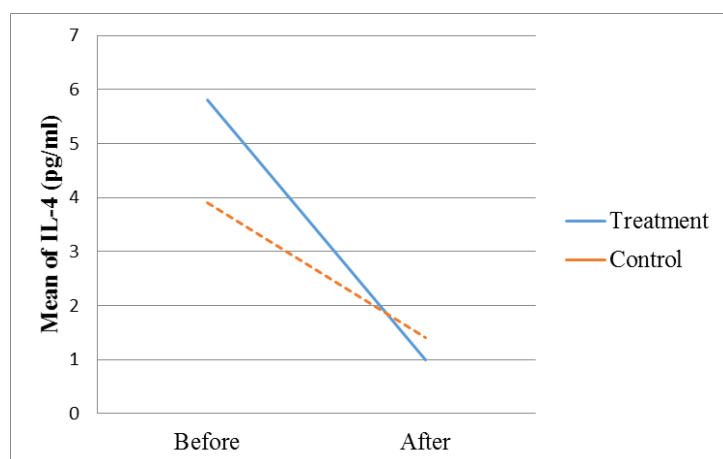

Figure 5. Mean of IL-4 serum between before and after intervention for 6 weeks
As shown in Table 2, mean zinc serum concentration after supplementation were higher at treatment group compared to placebo and was statistically significant. The control/placebo group also showed increase level of zinc serum; we suggest that the increase level maybe due to the awareness of the parents because we give general explanation and education before we recruit the subjects and informed consent. We did not performed analysis of diet consumption make us difficult to give details reason for this phenomena.

Figure 2 showed the delta $(X)$ increased level of zinc serum was statisticaly significant after supplementation at both groups $(\mathrm{p}<0.05)$. The mean delta increased level of zinc serum at treatment group was $24.74 \mathrm{ng} / \mathrm{dl}$ compare to control group $3.47 \mathrm{ng} / \mathrm{dl}$ which was significantly difference $(\mathrm{p}=0.00)$ (independent t-test).

In Figure 3, the decrease level of Ig-E serum were significantly different at two groups after zinc supplementation $(\mathrm{p}<0.05)$. Mean level decrease level of Ig-E at treatment group was $15.5 \mathrm{IU} / \mathrm{ml}$ compare to $20.02 \mathrm{IU} / \mathrm{ml}$ at control group according to MannWhitney $U$ test analysis was not signficantly different at both groups $(\mathrm{p}=0.613)$.

From Wilcoxon signed rank test analysis, the decrease level of IFN- $\gamma$ serum was significant after zinc supplementation at treatment group $(\mathrm{p}<0.05)$, meanwhile at control group according to paired t-test analysis showed no significant difference $(\mathrm{p}=0.323)$. The mean decrease level of IFN- $\gamma$ concentration was $1.82 \mathrm{pg} / \mathrm{ml}$ compare to $0.91 \mathrm{pg} / \mathrm{ml}$ at control group. According to Mann-Whitney U test analysis there were no significant difference on decrease level of IFN- $\gamma$ on both group ( $\mathrm{p}=0.714)$ (figure 4$)$.

Based on Wilcoxon signed rank test analysis, the decrease level of IL-4 serum before and after supplementation showed significant difference at both groups, at treatment group the decrease level of IL-4 concentration was not statistically significant $(\mathrm{p}=0.157)$. The mean decrease level of IL-4 concentration at treatment group was $4.76 \mathrm{pg} / \mathrm{ml}$ compare to $2.44 \mathrm{pg} / \mathrm{ml}$ at control group, and according to Mann-Whitney $U$ test there were no significant difference of mean decrease level of IL-4 serum at both group $(\mathrm{p}=0.085)$ (figure 5).

\section{DISCUSSION}

Our study showed high level of leptin suggesting that subjects on our study has leptin resistance. The leptin resistant which commonly found in obesity is identified as one factor for the risk. ${ }^{16,17}$ High level of leptin will lead the suppression of cytokine production of Th1 cells, but will increase the level production of Th2-cytokines such as IL-4, IL-5 and IL-13. In our study, lower level of IFN- $\gamma$ concentration on both group might be associated with higher level of leptin. ${ }^{18}$ Obesity is associated with increased risk factor of allergy. Studies showed that leptin resistance increases the event of bronchoconstriction and obesityassociated asthma. ${ }^{19,20}$ Atopy is associated with allergic diseases with family history predisposition. Clinical manifestation of allergy found in this research are 
atopic dermatitis, asthma and allergic rhinitis which associated with obesity. Boys are more frequent to have atopic manifestation compare to girls but not statistically significant. This result are different compare to study by Viera which showed that girls are more frequent to have asthma and atopy ${ }^{16}$. As we expected the IgE level were higher on both group because all subjects have risk of allergy based on positive family history with atopy supported by positive manifestation of allergy from anamnesis. The concentration of IL-4 were lower in both groups suggesting that leptin plays role on supressing the Th2 cell cytokine production of IL-4. ${ }^{21}$ Zinc supplementation associated with decreased level of IL4 concentration on both group but more pronounced in supplementation group suggesting that zinc supplementation decrease the risk of allergy.

Study by Tascilar on 34 obese children ages around 10 years old compare to normal weight showed that the zinc concentration was lower at obese children but not significantly different ${ }^{22}$. Other study support the previous study that the zinc concentration was lower at obese compare to normal weight, significantly ${ }^{23}$. In this study subjects showed lower zinc serum concentration in both groups in line with inclusion criteria. Zinc widely known as trace element who plays role in differentiation and development of cells. We suggest that in lower concentration of zinc serum, the cell proliferation will be limited which will disrupt specifically the T-cell proliferation, namely the balance of Th1 and Th2 cells, also its cytokine production. In our study there were no correlation between concentration of leptin and zinc of each group. Study by Chen showed that obese group have higher leptin concentration compare to normal weight; there were negative correlation between leptin and zinc concentration, suggesting that zinc play role towards leptin production at adipose tissue ${ }^{24}$.

Lower zinc concentration at obese individu will lead to imbalance of Th1/Th2 which effected on decrease level of Th1-cytokine production such as IFN- $\gamma$; widely will effect also the production of Th2cytokine production in lower impact compare to Th1. This study showed that in both group the IFN- $\gamma$ concentration was lower compare to normal. The concentration of $\mathrm{Ig}-\mathrm{E}$ was higher in both groups compare to normal; but the level of IL-4 were lower in both group. The result our study support the previous study stated that person with allergy produce lower concentration of IFN- $\gamma$, while Th2-cytokine production is less influenced which will make the person continue to produce Ig-E against exposure of environmental allergen $^{25}$.

Our study showed that zinc daily supplementation $15 \mathrm{mg}$ for 6 weeks influence the adaptive immune respond mediated by Th1 and Th2 cells on obese children who have family history of atopy. The level of zinc concentration are increased significantly. Zinc supplementation alters the level of Ig-E, IFN- $\gamma$ and IL4 serum; suggesting that increase level of zinc may play role on decreasing level of Ig-E and Th1- also Th2-cytokine production. These laboratory parameter lead us to the idea of improved level of zinc concentration will decrease the immune respond of Th2-mediated which will decrease or prevent the risk of allergy. The limitation of our study was that we did not control the diet consumption of subjects to eliminate the influence of additional zinc consumption; the other parts are the awareness of the parents towards obesity after education which might influence the result of zinc serum concentration. We did not measure the concentration of leptin after zinc supplementation and no re-examination the clinical manifestation of allergy. Further study emphasizing the improvement measurement find on the limitations of study hopefully will improve the result of this kind of study.

\section{CONCLUSIONS}

Zinc supplementation of $15 \mathrm{mg}$ once daily for 6 weeks improve the hypozincaemia state in obese children with family history of atopy, and associated with possible decreased risk of allergy.

\section{ACKNOWLEDGEMENTS}

This research was supported by The Head of National Institute of Health Research and Development stated on decree number: HK.02.04/I.1/1088/2013 on The determination of The Research Team on Development of Medical Science. Source of research funds was Project Budgeting Secretary of National Institute of Health Research and Development number: 024.11.1.416151/2013.

\section{REFERENCES}

1. Kral JG. (2001). Morbidity of severe obesity. Surg Clin North Am 8:1039-61.

2. Apandi PR, Setiabudiawan B, Sukadi A. (2001). Correlation between obesity with atopy and family history of atopy in children. Paediatrica Indonesiana 51:227-33.

3. Leung TF, Kong AP, Chan IH, Choi KC, Ho CS, Chan MH, et al. (2009). Association between obesity and atopy in Chinese schoolchildren. Int Arch Allergy Immunol 149(2):133-40.

4. Visness CM, London SJ, Daniels JL, Kaufman JS, Yeatts KB, Siega-Riz AM, et al. (2009). Association of Obesity with IgE and Allergy Sumptoms in Children and Adolescents: Results from NHANES 2005-2006. J Allergy Clin Immunol 123(5):1163-9

5. WHO Obesity and overweight. Cited from: http://www.who.int/news-room/fact-

sheets/detail/obesity-and-overweight 2018

6. Pacifico L, Di Renzo L, Anania C, Osborn JF, Ippoliti F, Schiavo E, et al. (2006). Increased Thelper interferon- $\gamma$-secreting cells in obese children. European Journal of Endocrinology 154:691-7.

7. Tateya S, Kim F, Tamori Y.(2013). Recent advances in obesity-induced inflammation and insulin resistance. Front Endocrinol (Lausanne) 4:1-14. doi:10.3389/fendo.2013.00093

8. Lappas M, Permezel M, Rice GE. (2005). Leptin and adiponectin stimulates the release of proinflammatory cytokines and prostaglandins 
from human placenta and maternal adipose tissue via nuclear factor- $\beta$, peroxisomal proliferatoractivated receptor- $\gamma$ and extracellularly regulated kinase 1/2. Endocrinology 146:3334-42. doi: 10.1210/en.2005-0406

9. Farooqi IS, Matarese G, Lord G, Keogh JM, Lawrence E, Agwu C, et al. (2002). Beneficial effects of leptin on obesity, $\mathrm{T}$ cell hyporesponsiveness, and neuroendocrine/metabolic dysfunction of human congenital leptin deficiency. Journal of Clinical Investigation 110:1093-103.

10. Matarese G, Moschos S, Mantzoros CS. (2005). Leptin in immunology. J Immunol 174:3137-42.

11. Yiannakouris N, Yannakoulia M, Melistas L, Chan JL, Klismis-Zacas D, Mantzoros CS. (2001). The Q223R pollymorphism of the leptine receptor gene is significantly associated wih obesity and predicts a small percentage of body weight and body composition variability. Clin Endoc Metab 86:4434-9.

12. Brunzell JD, Chait A. (2003). Lipoprotein Metabolism: Structure and Function. Els. http://www.els.net/WileyCDA/Elsarticle/reflda0000609

13. Kay AB. (2001). Allergy and allergic diseases. $N$ Engl J Med 334:30-7.

14. Marreiro DD, Cruz KJ, Morais JB, Beserra JB, Severo JS, de Oliveira AR. (2017). Zinc and Oxidative Stress: Current Mechanisms. Antioxidants 6(2):E24.

15. Marreiro DDN, Fisberg M, Cozzolino SMF. (2004). Zinc Nutritional Status and Its Relationships with Hyperinsulinemia in Obese Children and Adolescents. Biological Trace Elements 10:137-49.

16. Jr MGM, Leibel RL, Seeley RJ, Schwartz MW. Obesity and Leptin Resistance: Distinguishing Cause from Effect. Trends Endocrinol Metab. 2011;21(11):643-651.
17. Viera VJ, Ronan AM, Windt MR, Tagliaferro AR. (2005). Elevated atopy in healthy obesity women. Am J Clin Nutr 82:504-9.

18. Martin SS, Qasim A, Reilly MP. Leptin Resistance. A Possible Interface of Inflammation and Metabolism in Obesity-Related Cardiovascular Disease. J Am Coll Cardiol. 2008;52(15):1201-1210.

19. Arteaga-Solis E, Zee T, Emala CW, Vinson C, Wess J, Karsenty G. Inhibition of leptin regulation of parasympathetic signaling as a cause of extreme body weight-associated asthma. Cell Metab. 2013;17(1):35-48.

20. Khan AR, Awan FR. Leptin resistance: A possible iterface between obesity and pulmonary-related disorders. Int J Endocrinol Metab. 2016;14(1).

21. Youssef DM, Elbehidy RM, Shokry DM, Elbehidy M. The influence of leptin on Th1/Th2 balance in obese children with asthma. J Bras Pneumol. 2013;39(5):562-568.

22. Tascilar ME, Ozgen IT, Abaci A, Serdar M, Oykut O. (2011). Trace element in obesity Turkish children. Biol Trace Elem Res 143:188-95.

23. Marreiro D, Fisberg M, Cozzolino S. (2002). Zinc Nutritional Status in Obese Children and Adolescent. Biological Trace Element Research 107-22.

24. Chen MD, Song YM, Lin PY. (2000). Zinc may be a mediator of leptin production in humans. Life Science 66:2143-9.

25. Murphy K, Travers P, Walport M, editors. (2008). Janeway's Immunobiology $7^{\text {th }}$ ed. New York: Garland Science 2008 